\title{
Provenance and seed mass determine seed tolerance to high temperatures associated to forest fires in Pinus pinaster
}

\author{
Leonor Calvo $^{1}$ - Verónica Hernández ${ }^{1} \cdot$ Luz Valbuena $^{1}$ - Angela Taboada ${ }^{1,2}$
}

Received: 17 June 2015 / Accepted: 27 October 2015 / Published online: 20 November 2015

(C) INRA and Springer-Verlag France 2015

\begin{abstract}
- Key message We show that Pinus pinaster provenance affects both seed germination and seedling recruitment after fire. This information is crucial for managers to select the best seed-provisioning populations when implementing reforestation programs to assist the natural post-fire regeneration of the species.

- Context Reforestation programs to assist natural regeneration of maritime pine (Pinus pinaster Aiton) forests after wildfires very often neglect the fire-adaptive traits of the selected seed-source populations, threatening future stand resilience to fire.

- Aim We investigate the influence of seed provenance and weight on the rate and timing of seed germination, and on early seedling growth of $P$. pinaster after fire.

- Methods We simulated conditions during fire by experimentally submitting free seeds from three $P$. pinaster provenances with contrasting levels of serotiny (from $<6$ to $>58 \%$ of trees bearing serotinous cones within the population) to six
\end{abstract}

\section{Handling Editor: Eric Rigolot}

Contribution of the co-authors L. Calvo: coordinating the research project, experimental design, supervising the lab work, and writing and editing the paper

V. Hernández: lab work and editing the paper

L. Valbuena: experimental design, help in lab work, and help in editing the paper

A. Taboada: running the data analysis, and writing and editing the paper

Leonor Calvo

leonor.calvo@unileon.es

1 Area of Ecology, Faculty of Biological and Environmental Sciences, University of León, 24071 León, Spain

2 Institute of Environmental Research (IMA), University of León, 24071 León, Spain combinations of temperature and exposure time. We fitted GLMs and LMs to test for differences among provenances in reproductive performance after the thermal shock treatments.

- Results Heavy seeds derived from the very low serotinous population exhibited greater tolerance to heat (higher germination rate, lower germination time, and higher seedling length) than the lighter ones from the highly serotinous population.

- Conclusion The seeds enclosed in serotinous cones are, however, the only ones protected from high fire-induced temperatures, delaying release until favourable post-burn conditions for germination and seedling establishment. Therefore, selecting the best fire-adapted populations with the optimal serotiny level as seed-provisioning sources should be encouraged to ensure forest regrowth in fire-prone areas.

Keywords Post-fire regeneration - Seed germination · Seedling growth $\cdot$ Seed weight $\cdot$ Maritime pine

\section{Introduction}

The maritime pine (Pinus pinaster Aiton) is a very inflammable conifer species with high resin content that constitutes one of the principal fire-prone forest ecosystems of the Iberian Peninsula (Vasques et al. 2012). During 2012, 41 large wildfires (ranging from 511 to 28,879 ha) were recorded in Spain, which burned 135,580 ha in total (representing $63 \%$ of the total forested area burned in that year, a surface $300 \%$ higher than the average of the last decade), primarily affecting many large $P$. pinaster stands (Ministerio de Agricultura, Alimentación y Medio Ambiente 2014). As other Mediterranean pine species, such as Pinus halepensis Mill. and Pinus brutia Ten. (De las Heras et al. 2012), P. pinaster is an obligate 
seeder, i.e. non-resprouter species that relies only on regeneration from seeds for post-fire recovery (Pausas et al. 2004). The natural post-fire regeneration of $P$. pinaster occurs continuously until 3 years after a fire (Fernandes and Rigolot 2007; Madrigal et al. 2005), thanks to the long-lasting storage of seeds in serotinous cones (i.e. cones that release the seeds only after exposure to high temperatures) within the canopy level (Álvarez et al. 2005, 2007; Calvo et al. 2013; Fernandes and Rigolot 2007; Tapias et al. 2001, 2004; Torres et al. 2006). In the last 20 years, however, the post-fire recovery of $P$. pinaster has been undermined by the increased severity, extent, and recurrence of wildfires (with an interval between fires of less than 10-15 years, the minimum required time for adult pines to reach their reproductive maturity; Pausas et al. 2008; Tapias et al. 2001), together with extreme summer droughts and intense competition with resprouting species (Madrigal et al. 2011; Rodrigo et al. 2004). In this new situation, and given the commercial importance of the species, the Spanish National and Regional Forest Administrations develop seed collection programs, in which $P$. pinaster seeds are harvested from pre-selected outstanding trees in specific populations and preserved for silvicultural purposes. Seeds are then used in reforestation programs (either by direct seeding or by growing and planting new saplings), to enhance the recovery and ensure the survival of the stands devastated by high-intensity fires (see Gil et al. 2009).

$P$. pinaster forests exhibit a high geographic structuration of genetic variability at the intraspecific level in their whole distribution area (Bucci et al. 2007). Such variability is possibly related to the great variety of ecological conditions under which these forests develop, resulting in different life history strategies and peculiar population adaptations in terms of reproduction (Escudero et al. 2002; Gil et al. 2009; see also Bramlett et al. 1983), growth and survival (Alía et al. 1995), and response to fire (Ghildiyal et al. 2009). Variability in the reproductive traits (e.g. number of reproductive trees, cone production, and sapling and seedling density) of $P$. pinaster from different provenances also determines disparities in fire resilience among populations (Gil et al. 2009). Of the three genetic groups identified for $P$. pinaster (i.e. Atlantic, Mediterranean-European, and Maghrebian; Tapias et al. 2004), the Atlantic one shows the highest intra- and inter-population variability in fire adaptive traits, especially in the serotiny level (i.e. the percentage of serotinous cones varies among individuals of the same population and among different populations) (Tapias et al. 2001, 2004), which is a heritable character (Hernández-Serrano et al. 2014) closely related to the type of fire regime affecting each population (Hernández-Serrano et al. 2013; Tapias et al. 2004). Serotiny acts as an advantageous reproductive adaptation of $P$. pinaster populations in fire-prone environments, because (1) the canopy seed bank of the species is relatively small in non-serotinous populations (Tapias et al. 2001), and (2) the soil seed bank is insufficient and temporary and ends up irreversibly damaged either by fire-induced temperatures or by post-dispersal predation (De las Heras et al. 2012; Ruano et al. 2015; Torres et al. 2006). Populations with high levels of serotiny can retain closed cones up to 40 years and preserve seed viability for 30 years (Tapias et al. 2004) and are, therefore, more likely to survive frequent crown fires and achieve successful post-fire recruitment (i.e. high rates of seed germination and seedling emergence) (Fernandes and Rigolot 2007; Gil et al. 2009; Tapias et al. 2004). In contrast, non-serotinous or weakly serotinous populations display alternative strategies of fire adaptation (e.g. earlier and more abundant flowering, and the formation of a thick bark to protect the tree against lethal temperatures) that enable them to withstand low intensity fires (Fernandes and Rigolot 2007; Gil et al. 2009; Tapias et al. 2001, 2004). Such striking divergences in fire resilience and post-fire seedling recruitment among populations evidence the necessity of selecting the best fire-adapted $P$. pinaster provenances as seed sources in post-fire reforestation programs (Gil et al. 2009; Pausas 2015). Particularly in P. pinaster forests threatened by recurrent fires, the introduction of genetic material from populations with advantageous fire adaptive strategies (e.g. high levels of serotiny) is expected to improve natural regeneration in fire-devastated stands (Gil et al. 2009). However, there is a general lack of information on the species linking the serotiny level of the maternal population from which seeds are harvested and the resultant post-fire tree recruitment (Vega et al. 2008).

Moreover, extremely high variability in seed mass exists within and among $P$. pinaster provenances (Escudero et al. 2000; Zas and Sampedro 2015; Zas et al. 2013), similarly to other pine species (e.g. Court-Picon et al. 2004; Ganatsas et al. 2008; Liu et al. 2013; Parker et al. 2006). Seed mass is often positively associated with post-fire seedling establishment, growth, and survival (Álvarez et al. 2007; Bladé and Vallejo 2008; Escudero et al. 2000), but no consensus exists on the relationship between seed mass and germination rates following fire (Escudero et al. 2002; Hanley et al. 2003; Reyes and Casal 1995, 2004; Vasques et al. 2012). In the case of $P$. pinaster, heavier and larger seeds are less sensitive to high temperatures and more resistant to fire (Escudero et al. 1999, 2000; Reyes and Casal 1995, 2001) and are, therefore, thought to experience lower mortality during severe fires. Indeed, heavy seeds insulate the embryo better and preserve seed viability and survival, also favouring seedling performance, when submitted to diverse thermal shock treatments reproducing the effects of fire (Álvarez et al. 2007; Escudero et al. 2000; Reyes and Casal 2001). However, the effects of seed mass on post-fire recruitment may be more complex and very likely mediated by seed provenance, i.e. by the maternal environment and genotype (Cendán et al. 2013; Zas et al. 2013), from which seeds are harvested in reforestation programs.

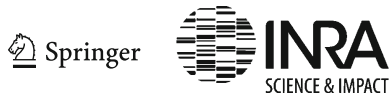


In this study, we aim to analyse the importance of the geographic origin and the variation in weight of the seed material used in reforestation programs for the post-fire regeneration of $P$. pinaster stands devastated by recurrent fires. In particular, we intend to evaluate the influence of (1) seed provenance and (2) seed weight on the reproductive performance (i.e. rate and time of seed germination, and early seedling growth and survival) of $P$. pinaster after fire. To achieve this aim, we simulate temperature conditions experienced during a wildfire by experimentally exposing the seeds from $P$. pinaster populations with contrasting serotiny levels to a number of heat shocks for different exposure times (Álvarez et al. 2005; Escudero et al. 1999, 2000; Martínez-Sánchez et al. 1995; Reyes and Casal 2001; Reyes et al. 2015).We expect the seeds obtained from highly serotinous populations to exhibit enhanced rate of seed germination at higher thermal shock temperatures (Fernandes and Rigolot 2007; Goubitz et al. 2003; Tapias et al. 2004). We also expect heavy seeds to germinate better (Reich et al. 1994; Reyes and Casal 2001) and produce larger seedlings (Castro 1999; Escudero et al. 2000; Reyes and Casal 2004) than light ones after exposure to the thermal treatments.

\section{Materials and methods}

\subsection{Seed material}

The biological material used in this study consisted of $P$. pinaster seeds collected from three different provenances belonging to the Atlantic genetic group (Tapias et al. 2004): (1) Tabuyo del Monte, henceforth 'Tabuyo', (León, Spain; $42^{\circ}$ $16^{\prime} 35^{\prime \prime} \mathrm{N} / 06^{\circ} 11^{\prime} 52^{\prime \prime} \mathrm{W}$, altitude $900 \mathrm{~m}$ a.s.l., mean annual temperature $9.7^{\circ} \mathrm{C}$, annual rainfall $752 \mathrm{~mm}$ ); (2) Sierra de Oña, henceforth 'Oña', (Burgos, Spain; 42 44' 33" $\mathrm{N} / 03^{\circ} 22^{\prime} 10^{\prime \prime} \mathrm{W}, 700 \mathrm{~m}, 10.8{ }^{\circ} \mathrm{C}, 685 \mathrm{~mm}$ ); and (3) Meseta Castellana-Coca, henceforth 'Coca', (Segovia, Spain; 41 ${ }^{\circ} 14^{\prime}$ $\left.31^{\prime \prime} \mathrm{N} / 04^{\circ} 29^{\prime} 60^{\prime \prime} \mathrm{W}, 810 \mathrm{~m}, 11.4^{\circ} \mathrm{C}, 474 \mathrm{~mm}\right)$. The three provenances differ in their life histories related to fire adaptation, particularly in the serotiny level (i.e. the percentage of trees with serotinous cones within the population) (Tapias et al. 2004): Tabuyo is classified as a highly serotinous provenance (more than $58 \%$ of serotinous trees), Oña as a moderately serotinous provenance (12-20\% of serotinous trees), and Coca as a very low serotinous provenance (less than $6 \%$ of serotinous trees).

Seeds were provided by the Forest Germplasm Bank of the National Centre of Forest Genetic Resources (Spanish Ministry of Agriculture, Food and Environment). Mature (i.e. brown-coloured) cones were randomly and extensively harvested in 2010 from pre-established stands within each population that are used as permanent seed-provisioning sources for research, conservation, and silvicultural management purposes by the Forest Germplasm Bank (total assigned harvesting area in each population: Tabuyo, 1779 ha; Oña, 820.7 ha; and Coca, 4187.4 ha; Ministerio de Agricultura, Alimentación y Medio Ambiente 2015). Since the stands have been selected by the experts of the National Centre of Forest Genetic Resources as representative of the genetic material of each population, we can, therefore, presume that they are as well equivalent to the studied populations in terms of the serotiny level (Tapias et al. 2004). All harvested cones were submitted to temperatures surpassing $45{ }^{\circ} \mathrm{C}$ by progressive drying by sun exposure, a procedure generally used to melt the resin seal that closes the scales and release the seeds without damage. Immediately after cone opening, the seeds were carefully extracted manually. Since both types of $P$. pinaster cones open below the attained temperatures (Tapias et al. 2001), the seed material obtained from each population may thus consist of a mixture of seeds released from nonserotinous and serotinous cones. This procedure for opening the vast majority of harvested cones and removing the seeds is assumed not to interfere with the results of the subsequent thermal shock treatments (see e.g. Habrouk et al. 1999; Moya et al. 2013; Reyes and Casal 2002; Salvatore et al. 2010). The released seeds were stored until their acquisition, under controlled optimal conditions to impede germination and preserve viability by the Forest Germplasm Bank. After purchase, we kept the seeds in open paper bags, which permitted ventilation, at laboratory temperature in a dry place until they were used.

Prior to the heat treatments, we characterised seed mass by weighting individually each of the seeds that were used in the experiment (i.e. 700 seeds per provenance, 2100 seeds in total). We then randomly divided the seeds in 105 groups of 20 seeds (i.e. 35 groups per provenance) and calculated the average seed weight value for each group or replicate for statistical analyses. The groups of seeds were randomly assigned to the thermal shock treatments.

Also, seed viability assays on 100 additional seeds per provenance (i.e. five replicates of 20 seeds) were performed using the tetrazolium test according to standard procedures (Besnier Romero 1989). The seeds were sectioned to expose the embryo, placed in five Petri dishes (i.e. 20 seeds per dish), and submerged in $1 \%$ solution of tetrazolium. After $24 \mathrm{~h}$, seeds whose embryos had stained red were classified as viable. The percentage of seed viability was determined for each of the five replicates of 20 seeds per provenance.

\subsection{Thermal shock treatments}

In 2012, a total of 600 seeds per $P$. pinaster provenance (i.e. 30 groups of 20 seeds per provenance) were submitted to different thermal shocks and another 100 seeds (i.e. five groups of 20 seeds per provenance) were used as a control. Seeds were subjected to six combinations of temperature $(100,150$ and $200^{\circ} \mathrm{C}$ ) and exposure time ( 1 and $5 \mathrm{~min}$ ), using a dry air oven. 
These combinations were selected after Trabaud (1979) and Moya et al. (2008), to simulate heat conditions acting in the course of a stand-replacement fire (that affects both the surface and the crown layer) on free seeds released from nonserotinous cones at the ground surface and on seeds enclosed in serotinous cones at the canopy level (see also Moya et al. 2013; Reyes et al. 2015). According to Trabaud (1979), temperatures reached at the soil surface during a natural fire can vary between 60 and $150{ }^{\circ} \mathrm{C}$ for a short period of time (between 1 and $15 \mathrm{~min}$ ). According to Moya et al. (2008), temperatures reached at seed location inside serotinous cones of $P$. halepensis Mill within the canopy layer can raise up to $70{ }^{\circ} \mathrm{C}$ during a few seconds after $3 \mathrm{~min}$ of fire exposition. The seeds from all provenances were submitted to the thermal treatments at a time, in pre-heated ceramic capsules containing 20 seeds each (i.e. 5 ceramic capsules per provenance, 15 ceramic capsules per treatment in total). There were, therefore, five replicates of 20 seeds per thermal shock and control treatment in each provenance (i.e. sample size $=5$ replicates $\times 7$ treatments $\times 3$ provenances $=105$ ).

Immediately after the thermal shocks, each group of 20 seeds per heat shock and provenance was sown in an 8.5$\mathrm{cm}$-diameter Petri dish on four sheets of filter paper saturated with demineralised water to avoid desiccation (105 dishes in total). The dishes were placed in a controlled environment cabinet at a temperature of $20 \pm 1{ }^{\circ} \mathrm{C}$ with photoperiods of 15-h light/9-h dark, watered twice per week, and examined once per week to determine the rate and time of seed germination. The use of a temperature of $20{ }^{\circ} \mathrm{C}$ is comparable to other germination studies in which temperatures varied between 20 and $23{ }^{\circ} \mathrm{C}$ (Trabaud and Oustric 1989). A seed was considered to have germinated when the radicle could be seen with the naked eye (Côme 1970). Seeds were inspected for germination for 63 days in total, using the method proposed by Martínez-Sánchez et al. (1995), according to which the experiment ends after approximately 10 days without germination. We calculated the percentage of seed germination and the average seed germination time after the thermal treatments for each of the five replicates of 20 seeds per treatment in each provenance. The average germination time $\left(t_{\mathrm{m}}\right)$ was calculated using the following formula (Côme 1970):

$t_{\mathrm{m}}=\frac{N_{1} T_{1}+N_{2} \ldots+N_{\mathrm{n}} T_{\mathrm{n}}}{N_{1}+N_{2} \ldots+N_{\mathrm{n}}}$,

where $N_{1}$ is the number of seeds that have germinated during time $T_{1}, N_{2}$ is the number of seeds that have germinated between time $T_{1}$ and time $T_{2}$, and so on.

As soon as a seed had germinated, it was individually transplanted into a plastic pot $(7.5 \times 7.5 \times 8 \mathrm{~cm})$, placed in a controlled temperature area, and watered once per week with demineralised water. Due to mortality risks, and to ensure that a minimum of five seedling replicates per treatment and provenance combination would survive until the end of the growing period, the first 12 germinated seeds from each thermal treatment (except $200{ }^{\circ} \mathrm{C}$ during $5 \mathrm{~min}$, after which insufficient seed germination occurred) and provenance were transplanted (i.e. 216 seedlings in total). Five weeks after the germination of each individual seed, we measured the length of both the aerial part of the stem and the subterranean root of every seedling that had survived using a digital calliper. We determined the total length of every seedling by summing up the aerial and subterranean length measurements, and we randomly selected five total seedling length values per thermal treatment in each provenance for statistical analyses.

\subsection{Statistical analysis}

We first analysed the differences in seed viability and weight among the three $P$. pinaster provenances (Coca, Oña, and Tabuyo) by performing a generalised linear model (GLM) and a linear model (LM), respectively. We modelled seed viability data following a quasi-Poisson error distribution, using the logit link function, and seed weight data following a Gaussian error distribution using the identity link function.

We also used GLMs and LMs to test for differences in seed germination rate, seed germination time and seedling length after the thermal shock treatments. We modelled seed germination rate data following a quasi-Poisson error distribution to account for overdispersion, and seed germination time and seedling length data following a Gaussian error distribution. The predictor variables in the models were seed weight (i.e. the average seed weight value for each replicate), seed provenance, thermal shock treatment (i.e. control, $100{ }^{\circ} \mathrm{C}$ for $1 \mathrm{~min}, 100{ }^{\circ} \mathrm{C}$ for $5 \mathrm{~min}, 150{ }^{\circ} \mathrm{C}$ for $1 \mathrm{~min}, 150{ }^{\circ} \mathrm{C}$ for $5 \mathrm{~min}, 200^{\circ} \mathrm{C}$ for $1 \mathrm{~min}$, and $200^{\circ} \mathrm{C}$ for $5 \mathrm{~min}$ ), and the interaction between seed provenance and thermal shock treatment. The average seed weight value was included as the first predictor variable in the models to account for interprovenance variability in seed weight (see below) and test whether seed provenance still affects seed tolerance to heat shocks after removing the main effect of seed weight. The predicted values of seed germination rate after the different thermal shock treatments were obtained from the GLMs for the observed range of seed weight values in each provenance. The predicted values of seed germination time and total seedling length after the different thermal shock treatments were obtained from the LMs for the mean seed weight of all three provenances.

All data analyses were carried out with R software, version 3.1.1 (R Core Team 2014) using the 'stats' and 'MASS' (Venables and Ripley 2002) packages. 


\section{Results}

\subsection{Seed viability and weight}

We found no significant differences $\left(\chi^{2}=0.29, P=0.867\right)$ in seed viability among the three $P$. pinaster provenances. Almost all seed viability values were higher than $95 \%$ indicating that nearly all the seeds subjected to the thermal shock treatments were capable of germinating. There were significant differences $(F=47.34, P<0.001)$ in seed weight among provenances, with the highest values measured in Coca and the lowest in Tabuyo (Fig. 1).

\subsection{Seed germination rate}

The percentage of seed germination after the thermal shocks was significantly affected by seed weight, seed provenance, and the type of thermal shock treatment applied (Table 1). The significant effect of provenance after removal of the main effect of seed weight indicates that there may be relevant features related to the origin of seed populations other than differences in seed weight that are very much affecting seed germination success. The effect of the thermal shocks on the rate of seed germination differed among provenances (i.e. significant interaction term). In general, the rate of seed germination increased with increasing seed weight in all three provenances (Fig. 2). Also, the provenance with the heaviest seeds (Coca) showed the highest seed germination rates after all the thermal treatments, while the provenance with the lightest seeds (Tabuyo) showed the lowest. The percentage of seed germination decreased consistently across all three provenances after subjecting the seeds to the heat treatments of 100,150 and $200^{\circ} \mathrm{C}$ for $5 \mathrm{~min}$. Moreover, no seed germination was detected in Oña after the heat treatment of $200^{\circ} \mathrm{C}$ for $5 \mathrm{~min}$. Compared to the control, the percentage of seed germination increased only after the heat treatments of 100 and $150{ }^{\circ} \mathrm{C}$ for $1 \mathrm{~min}$ in Coca and Tabuyo, and $200^{\circ} \mathrm{C}$ for $1 \mathrm{~min}$ in Coca.

\subsection{Seed germination time}

The average seed germination time after the thermal shock treatments was significantly affected by seed provenance and the type of thermal shock treatment applied, but not by seed weight (Table 2). Other features related to seed provenance besides differences in seed weight are, therefore, very likely affecting the time at which the seeds germinate. We also found a significant interaction between seed provenance and thermal treatment. The lowest germination time was found in Coca (except after the heat treatment of $200{ }^{\circ} \mathrm{C}$ for $5 \mathrm{~min}$ ), where the predictions of seed germination time ranged between 14 and 20 days (Fig. 3). Compared to the control, the average germination time consistently increased after all

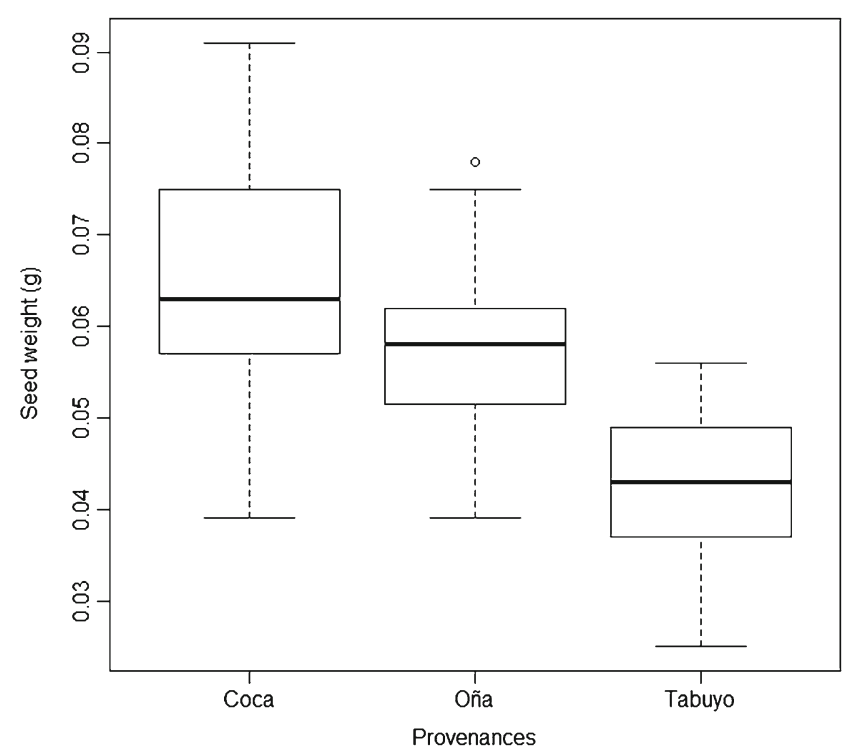

Fig. 1 Boxplot diagram of the seed weight values of Pinus pinaster for each provenance (Coca, Oña, and Tabuyo) $(N=35$ weight values $\times 3$ provenances $=105$ ). Each seed weight value was calculated by averaging the individual weight values of a group of 20 seeds (see text for further details). The horizontal line shows the median seed weight, while the bottom and top of the box show the 25th and 75th percentiles, respectively (i.e. the location of the middle $50 \%$ of the data, also called the first and third quartiles)

thermal treatments (except $200{ }^{\circ} \mathrm{C}$ for $5 \mathrm{~min}$ ) in Oña, where the predicted seed germination time ranged between 19 and 26 days. The greatest variability in seed germination time corresponded to Tabuyo (predicted values between 14 and 32 days), where no clear pattern of response was found in relation to the thermal treatments. Under control conditions, we detected a negative relationship between germination time and seed weight.

\subsection{Seedling length}

Germinated seeds from the three provenances that had been exposed to the heat treatment of $200{ }^{\circ} \mathrm{C}$ for 5 min failed to grow and survive under laboratory conditions, and, therefore, not enough seedlings were obtained from this particular treatment. Seedling length was significantly affected by seed provenance, but not by seed weight or by the thermal shock treatments to which the seeds were subjected (Table 3). Therefore, excluding differences in seed weight, other relevant factors related to seed provenance are, in all probability, having an effect on seedling length. The response of seedling length to the different seed thermal treatments showed no general trend and varied among seed provenances (i.e. significant interaction term; Table 3 and Fig. 4). Compared to the control, seedling length decreased after the thermal treatments in the case of Coca, while it primarily increased in the case of Oña. The greatest reduction in seedling length was recorded in Tabuyo, when submitting the seeds to the heat treatments of 100 and 
Table 1 Generalised linear model (GLM) results for the effects of seed weight, seed provenance (i.e. the geographic origin of the maternal seed population), seven different thermal shock treatments, each consisting in a combination of temperature and exposure time (i.e. control, $100{ }^{\circ} \mathrm{C}$ for
$1 \mathrm{~min}, 100^{\circ} \mathrm{C}$ for $5 \mathrm{~min}, 150^{\circ} \mathrm{C}$ for $1 \mathrm{~min}, 150{ }^{\circ} \mathrm{C}$ for $5 \mathrm{~min}, 200^{\circ} \mathrm{C}$ for $1 \mathrm{~min}$, and $200{ }^{\circ} \mathrm{C}$ for $5 \mathrm{~min}$ ), and the interaction between seed provenance and thermal shock treatment, on the rate of seed germination of Pinus pinaster

\begin{tabular}{llllll}
\hline Variable & Df & Deviance & Residual Df & Residual deviance & $\chi^{2}$ value \\
\hline Null & & & 104 & 2194 & \\
Seed weight & 1 & 23.8 & 103 & 2170 & 9.1 \\
Seed provenance & 2 & 162.4 & 101 & 2008 & 62.4 \\
Thermal shock treatment & 6 & 1513 & 95 & 494.8 & $<003$ \\
Seed provenance * thermal shock treatment & 12 & 272.6 & 83 & 222.2 & $<0.1$ \\
\hline
\end{tabular}

Each seed weight value was calculated by averaging the individual weight values of a group of 20 seeds that make up each of the 5 replicates per heat treatment and provenance. $N=5$ replicates $\times 7$ treatments $\times 3$ provenances $=105$. $\mathrm{Df}=$ degrees of freedom

$150{ }^{\circ} \mathrm{C}$ for $5 \mathrm{~min}$. Under control conditions, we detected a positive relationship between seedling length and seed weight.

\section{Discussion}

Our results evidenced a clear effect of seed provenance on the rate and timing of seed germination and on early seedling growth, thus confirming the relevance of the geographic origin of the mother trees selected in reforestation programs for the regeneration of $P$. pinaster after fire. Prior research on the species showed strong effects of the maternal environment (i.e. the conditions where the mother tree grows) on seed germination (Cendán et al. 2013) and seedling performance (Zas et al. 2013), partly mediated by differences in seed weight between mother trees, as well as on seedling resistance to biotic stress (Vivas et al. 2013). Research further indicates that the origin of seeds sown after a fire eventually determines the canopy structure and the amount of cone production of a regenerated stand, as a result of contrasting adaptive traits between mother tree populations, particularly the serotiny level (Gil et al. 2009; Vega et al. 2008). In our study, the three populations exhibiting distinct serotiny levels significantly differ in their average seed weight and responded dissimilarly not just under control conditions but also after the thermal shocks simulating the effects of fire. The population with the highest percentage of trees bearing serotinous cones had significantly lighter seeds of possibly lower quality (Álvarez et al. 2007; Bladé and Vallejo 2008) and underwent poorer natural regeneration under control conditions (i.e. lower rate of seed germination, higher seed germination time, and lower seedling length). Correspondingly, the population with the lowest percentage of trees with serotinous cones had significantly heavier seeds that performed better under control conditions (i.e. higher rate of seed germination, lower seed germination time, and higher seedling length). Subjecting the seeds to the thermal shocks accentuated such differences to a certain degree, since heavier seeds displayed even greater germination rate and lower germination time than the lighter ones, but did not produce seedlings with markedly higher length. As a consequence, and contrary to our expectations, the population with the highest percentage of serotinous trees did not respond better to the different heat shocks under laboratory conditions than the other two populations with lower serotiny levels.
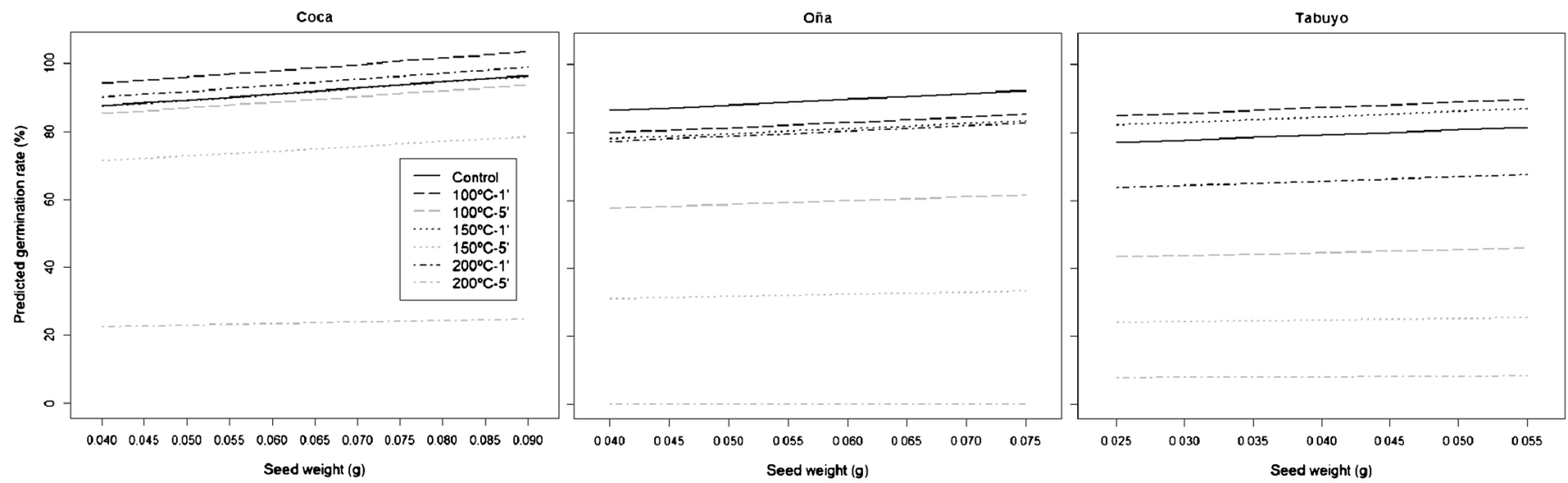

Fig. 2 Mean predicted values of the seed germination rate of Pinus pinaster after the different thermal shock treatments in each provenance (Coca, Oña, and Tabuyo). Generalised linear model (GLM) predictions were obtained for the observed range of seed weight values in each provenance 
Table 2 Linear model (LM) results for the effects of seed weight, seed provenance (i.e. the geographic origin of the maternal seed population), seven different thermal shock treatments, each consisting in a combination of temperature and exposure time (i.e. control, $100{ }^{\circ} \mathrm{C}$ for
$1 \mathrm{~min}, 100{ }^{\circ} \mathrm{C}$ for $5 \mathrm{~min}, 150{ }^{\circ} \mathrm{C}$ for $1 \mathrm{~min}, 150{ }^{\circ} \mathrm{C}$ for $5 \mathrm{~min}, 200^{\circ} \mathrm{C}$ for $1 \mathrm{~min}$ and $200^{\circ} \mathrm{C}$ for $5 \mathrm{~min}$ ), and the interaction between seed provenance and thermal shock treatment, on the average time of seed germination of Pinus pinaster

\begin{tabular}{|c|c|c|c|c|c|}
\hline Variable & $\mathrm{Df}$ & Sum of squares & Mean squares & $F$ value & $P$ value \\
\hline Seed weight & 1 & 43.7 & 43.7 & 2.6 & 0.110 \\
\hline Seed provenance & 2 & 176.3 & 88.2 & 5.3 & 0.007 \\
\hline Thermal shock treatment & 6 & 1526 & 254.4 & 15.2 & $<0.001$ \\
\hline Seed provenance $*$ thermal shock treatment & 12 & 1937 & 161.4 & 9.7 & $<0.001$ \\
\hline Residuals & 83 & 1389 & 16.7 & & \\
\hline
\end{tabular}

Each seed weight value was calculated by averaging the individual weight values of a group of 20 seeds that make up each of the 5 replicates per heat treatment and provenance. $N=5$ replicates $\times 7$ treatments $\times 3$ provenances $=105$. $\mathrm{Df}=$ degrees of freedom

Previous empirical observations have demonstrated the benefits of yielding bigger seeds under stressful environments (e.g. Metz et al. 2010; Moles and Westoby 2004; Stock et al. 1990; Violle et al. 2009; Zas et al. 2013). Favouring seeds as heavy as possible to the detriment of a higher number of light seeds allows the plant to develop bigger embryos with greater vitality and amount of reserves (Delgado et al. 2001) and to give rise to more vigorous seedlings with lower mortality rate (Castro 1999; Escudero et al. 2000; Moles and Westoby 2004; Reyes and Casal 2001; but see Moles and Westoby 2006). Heavy seeds are also thought to exhibit higher resistance to heat (Álvarez et al. 2007; Delgado et al. 2001; Reyes and Casal 1995), providing the plant with an advantageous adaptive trait against frequent fires (Escudero et al. 1999; Keeley 1977; Reyes and Casal 2001). Yet, our findings do not support the role of the fire regime as a strong selective pressure for the evolution of great seed mass, since the bigger seeds derived from the moderately serotinous and very low serotinous populations evolved under less recurrent fires (Tapias et al. 2004), and the lighter ones from the highly serotinous population subjected to frequent crown fires (Tapias et al. 2004).

Our results are, instead, consistent with the differences in weight between seeds stored in serotinous and non-serotinous cones earlier described in other Mediterranean pines (De las Heras et al. 2012; Salvatore et al. 2010): The population with the highest number of trees bearing serotinous cones displayed the lowest average seed weight value, and vice versa. Even though the seed material in our study may consist of a mixture of seeds harvested from serotinous and nonserotinous cones, it seems reasonable to assume that the majority of seeds harvested in one population derive from the prevailing type of cone in that population (e.g. seeds collected from the population with the highest percentage of serotinous trees would be mostly harvested from serotinous cones). It might therefore be the case that the poorer response of the lighter seeds harvested from the population with the highest serotiny level to the heat shocks under laboratory conditions was the result of them being protected from high fire-induced temperatures in the field by serotinous cones. Serotinous cones favour seed physiological and anatomical resistance to fire (Moya et al. 2013; Salvatore et al. 2010), provide effective seed mechanical and thermal defence (Fernandes and Rigolot 2007; Moya et al. 2008), guarantee seed viability in the course of a high-severity fire (Reyes and Casal 2002) and promote rapid post-fire establishment of seedlings, owing to a massive discharge of seeds triggered by heat (De las Heras et al. 2012). The seeds enclosed in serotinous cones are released several days after a fire, delaying germination until temperature at surface level is decreased, and thus benefiting from optimal post-burn conditions for germination and seedling establishment (i.e. high availability of space and nutrients, low competition for water and light and low predation risk) (HernándezSerrano et al. 2013; Saracino et al. 1997). Oppositely, the seeds stored in non-serotinous cones may be very adapted to germinate promptly and grow under less favourable

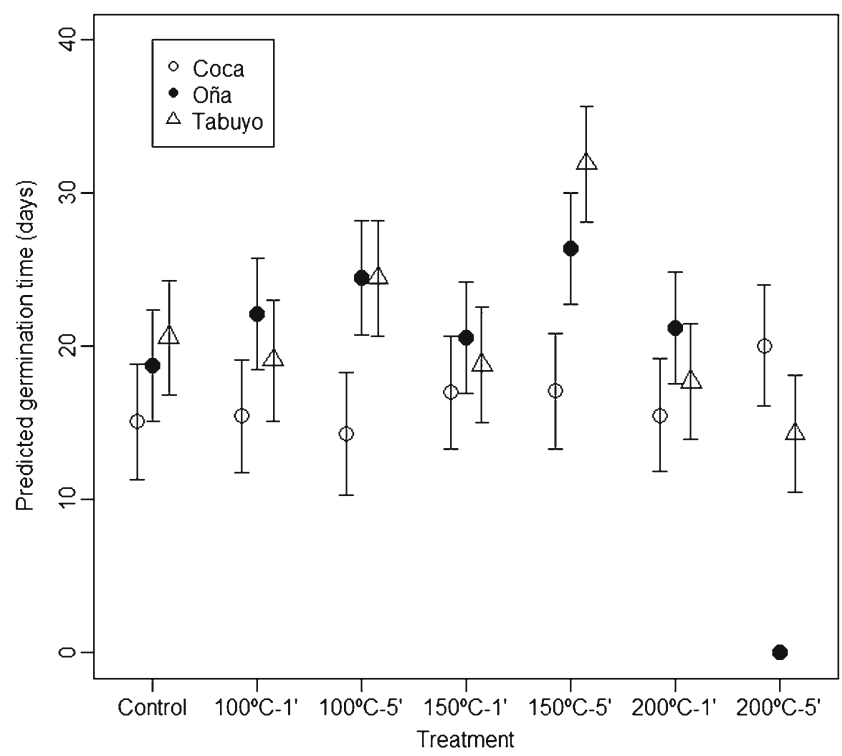

Fig. 3 Predicted values (mean $\pm 95 \%$ confidence intervals) of the seed germination time of Pinus pinaster after the different thermal shock treatments in each provenance (Coca, Oña, and Tabuyo). Linear model (LM) predictions were obtained for the mean seed weight of all provenances 
Table 3 Linear model (LM) results for the effects of seed weight, seed provenance (i.e. the geographic origin of the maternal seed population), six different thermal shock treatments, each consisting in a combination of temperature and exposure time (i.e. control, $100^{\circ} \mathrm{C}$ for $1 \mathrm{~min}, 100{ }^{\circ} \mathrm{C}$ for $5 \mathrm{~min}, 150{ }^{\circ} \mathrm{C}$ for $1 \mathrm{~min}, 150^{\circ} \mathrm{C}$ for $5 \mathrm{~min}$ and $200^{\circ} \mathrm{C}$ for $1 \mathrm{~min}$ ), and the interaction between seed provenance and thermal shock treatment, on the total seedling length of Pinus pinaster

\begin{tabular}{|c|c|c|c|c|c|}
\hline Variable & Df & Sum of squares & Mean squares & $F$ value & $P$ value \\
\hline Seed weight & 1 & 1.6 & 1.6 & 0.3 & 0.578 \\
\hline Seed provenance & 2 & 36.9 & 18.4 & 3.5 & 0.035 \\
\hline Thermal shock treatment & 5 & 61.0 & 12.2 & 2.3 & 0.052 \\
\hline Seed provenance $*$ thermal shock treatment & 10 & 174.0 & 17.4 & 3.3 & 0.001 \\
\hline Residuals & 71 & 373.0 & 5.3 & & \\
\hline
\end{tabular}

Each seed weight value was calculated by averaging the individual weight values of a group of 20 seeds that make up each of the 5 replicates per heat treatment and provenance. Germinated seeds that had been exposed to the heat treatment of $200{ }^{\circ} \mathrm{C}$ for 5 min failed to grow and survive under laboratory conditions, and, therefore, no seedlings were obtained from this particular treatment to be included in the analyses. $N=5$ replicates $\times 6$ treatments $\times 3$ provenances $=90 . \mathrm{Df}=$ degrees of freedom

conditions (Hernández-Serrano et al. 2013), since these cones open at relatively low temperatures, easily reached through summertime in the Mediterranean basin (Tapias et al. 2001). Where subjected to a crown fire, non-serotinous cones very likely release the seeds before the arrival of the flame front, when air temperature rises from ambient to hundreds of degrees in a few seconds (Odion and Davis 2000), melting the resin seal that closes the scales (see Alexander and Cruz 2012). The seeds at the soil surface might then be exposed to extremely high flame temperatures (Certini 2005), which could have acted as a major selective force favouring specific seed resistance mechanisms to heat damage. These seeds might, too, have compensated the lack of protection in nonserotinous cones by obtaining greater embryo insulation via increased seed mass and a thicker seed coat (Escudero et al. 1999; Salvatore et al. 2010). Such adaptations of seeds enclosed in non-serotinous cones are perhaps responsible for the better response to the heat shocks of the seeds harvested from the population with the lowest number of trees bearing serotinous cones.

Under laboratory conditions, seed viability after the thermal shocks was preserved in all three populations even when temperatures reached $200^{\circ} \mathrm{C}$, except when seeds were submitted to prolonged times of temperature exposure (i.e. $5 \mathrm{~min}$ ) that also generally caused a sharp decrease in germination. These findings agree with previous results by Álvarez et al. (2005) and Torres et al. (2006), but somewhat contradicted those by Escudero et al. (1999) and Martínez-Sánchez et al. (1995). When translating these results to real wildfire scenarios, however, the viability of seeds may not be preserved at the surface level, where both fire intensity and duration very often exceed lethal values and destroy the majority of free seeds that had earlier been released from non-serotinous cones (Habrouk et al. 1999). Seed viability appears, hence, to be safeguarded solely inside those serotinous cones that remain closed within the canopy level and are not ignited or scorched by direct flame contact (Alexander and Cruz 2012; Fernandes and Rigolot
2007; Reyes and Casal 2002). Yet, variation in cone serotiny among individual trees of the same population provides $P$. pinaster and other Mediterranean pines with a dual strategy for ensuring (1) tree recruitment in fire-free periods, and (2) fire-heat resistance and post-fire successful regeneration (De las Heras et al. 2012; Gil et al. 2009; Goubitz et al. 2004; Moya et al. 2008, 2013). Changing the percentage of trees bearing serotinous cones in the population could, therefore, result in the failure of tree regeneration and the loss of fire resilience, leading to important difficulties in forest regrowth in the framework of future, more severe and frequent fires and more extreme weather conditions (Espelta et al. 2011; Moriondo et al. 2006; Pausas 2004). For this reason, the first priority of postfire restoration programs designed to assist natural

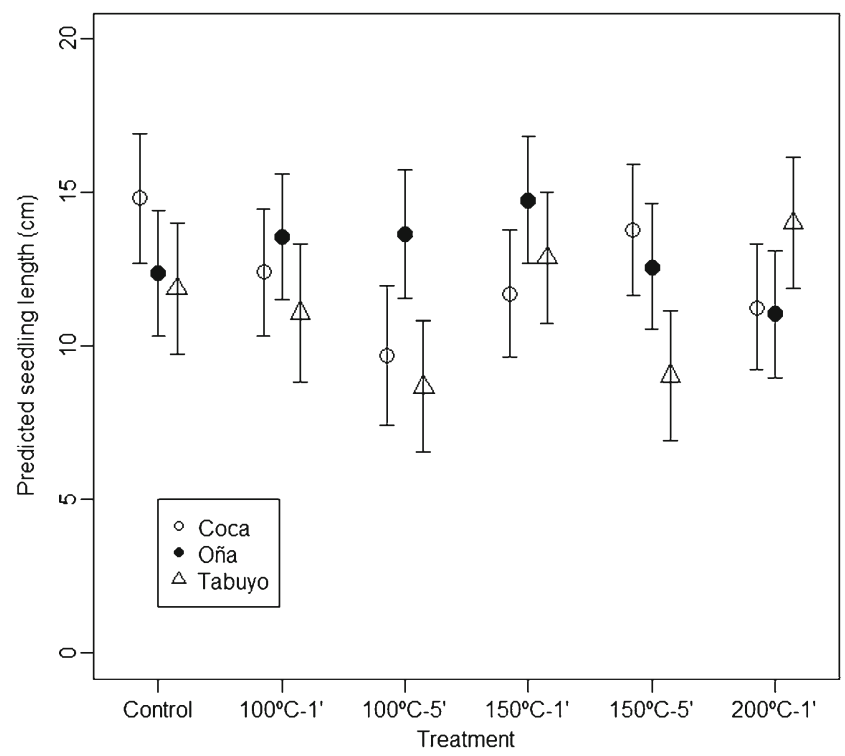

Fig. 4 Predicted values (mean $\pm 95 \%$ confidence intervals) of total seedling length of Pinus pinaster after the different thermal shock treatments in each provenance (Coca, Oña, and Tabuyo). Linear model (LM) predictions were obtained for the mean seed weight of all provenances 
regeneration in fire-prone areas should be to preserve pine stand resistance and resilience to new fires, by selecting the best fire-adapted populations with the optimal serotiny level as seed-provisioning sources (De las Heras et al. 2012; Gil et al. 2009; Moya et al. 2013; Pausas 2015). Restoration programs should further try to maximise natural pine recruitment, by preferentially harvesting the seeds from mother trees growing in non-stressful environments within the selected populations (i.e. mother trees producing heavy seeds with proven superior germination and seedling growth) (see Espelta et al. 2011; Zas et al. 2013). To what extent these practices aimed at selecting the best seed sources in post-fire restoration programs may allow fire-prone pine ecosystems to cope with new fire regime scenarios in the Mediterranean basin is still unknown and certainly deserves future attention (Pausas 2015).

\section{Conclusions}

Free seeds harvested from $P$. pinaster populations with contrasting levels of serotiny responded differently to fire: heavy seeds from the very low serotinous population had much greater resistance to the thermal shocks than the lighter ones from the highly serotinous population. These unexpected findings may be, above all, explained by the distinct reproductive and fire-adaptive strategies of trees predominantly bearing non-serotinous and serotinous cones in these populations (Goubitz et al. 2003). Seeds enclosed in non-serotinous cones are released annually under warm and dry weather conditions and eventually display prompt germination to withstand competition. In the event of a fire, the discharge of seeds from nonserotinous cones is triggered by heat, causing most of these seeds at the ground surface to end up being killed by the fire (Habrouk et al. 1999). The seeds retained inside serotinous cones are otherwise protected from high fire-induced temperatures and encounter optimal germination conditions when massively released several days after fire.

Where post-fire reforestation programs are developed to assist natural regeneration, selecting the best fire-adapted populations with the optimal serotiny level as seed-provisioning sources may be, therefore, crucial for these fire-prone pine ecosystems to cope with the predicted future, more catastrophic, fire scenarios (Pausas 2015; Pausas et al. 2008).

\begin{abstract}
Acknowledgments Two anonymous reviewers provided very valuable comments on the manuscript. The study was financially supported by the Spanish Ministry of Economy and Competitiveness, and the European Regional Development Fund (ERDF), in the frame of the GESFIRE project (AGL2013-48189-C2-1-R); and by the Regional Government of Castilla and León in the frame of the FIRECYL project (LE033U14).
\end{abstract}

\section{Compliance with ethical standards}

Funding The study was financially supported by the Spanish Ministry of Economy and Competitiveness, and the European Regional
Development Fund (ERDF), in the frame of the GESFIRE project (AGL2013-48189-C2-1-R); and by the Regional Government of Castilla and León in the frame of the FIRECYL project (LE033U14).

\section{References}

Alexander ME, Cruz MG (2012) Modelling the effects of surface and crown fire behaviour on serotinous cone opening in jack pine and lodgepole pine forests. Int J Wildland Fire 21:709-721. doi:10. 1071/WF11153

Alía R, Gil L, Pardos JA (1995) Performance of 43 Pinus pinaster provenances on 5 locations in Central Spain. Silvae Genet 44:75-81

Álvarez R, Valbuena L, Calvo L (2005) Influence of tree age on seed germination response to environmental factors and inhibitory substances in Pinus pinaster. Int J Wildland Fire 14:277-284. doi:10. 1071/WF04066

Álvarez R, Valbuena L, Calvo L (2007) Effect of high temperatures on seed germination and seedling survival in three pine species (Pinus pinaster, $P$. sylvestris and P. nigra). Int J Wildland Fire 16:63-70. doi:10.1071/WF06001

Besnier Romero F (1989) Semillas. Biología y tecnología, Mundiprensa, Madrid

Bladé C, Vallejo VR (2008) Seed mass effects on performance of Pinus halepensis Mill. seedlings sown after fire. For Ecol Manag 255: 2362-2372. doi:10.1016/j.foreco.2007.12.039

Bramlett DL, Dell TR, Pepper WD (1983) Genetic and maternal influences on Virginia pine seed germination. Silvae Genet 32:1-4

Bucci G, González-Martínez SC, Le Provost G, Plomion C, Ribeiro MM, Sebastiani F, Alía R, Vendramin GG (2007) Range-wide phylogeography and gene zones in Pinus pinaster Ait. revealed by chloroplast microsatellite markers. Mol Ecol 16:2137-2153. doi:10. 1111/j.1365-294X.2007.03275.x

Calvo L, Torres O, Valbuena L, Luis E (2013) Recruitment and early growth of Pinus pinaster seedlings over five years after a wildfire in NW Spain. Forest Syst 22:582-586. doi:10.5424/fs/201322304623

Castro J (1999) Seed mass versus seedling performance in Scots pine: a maternally dependent trait. New Phytol 144:153-161. doi:10.1046/ j.1469-8137.1999.00495.x

Cendán C, Sampedro L, Zas R (2013) The maternal environment determines the timing of germination in Pinus pinaster. Environ Exp Bot 94:66-72. doi:10.1016/j.envexpbot.2011.11.022

Certini G (2005) Effects of fire on properties of forest soils: a review. Oecologia 143:1-10. doi:10.1007/s00442-004-1788-8

Côme D (1970) Les obstacles à la germination. Mason, Paris

Court-Picon M, Galbin-Henry C, Guibal F, Roux M (2004) Dendrometry and morphometry of Pinus pinea L. in Lower Provenance (France): adaptability and variability of provenances. For Ecol Manag 194: 319-333. doi:10.1016/j.foreco.2004.02.024

Ministerio de Agricultura, Alimentación y Medio Ambiente (2014) Incendios forestales en España año 2012. [Retrieved on: 28/09/ 2014, available at: http://www.magrama.gob.es/es/biodiversidad/ estadisticas/Incendios_default.aspx]

Ministerio de Agricultura, Alimentación y Medio Ambiente (2015). Catálogo Nacional de Materiales de Base para la producción de Material Forestal de Reproducción Identificado: Pinus pinaster Ait. [Retrieved on: 13/09/2015, available at: http://www.magrama. gob.es/es/desarrollo-rural/temas/politica-forestal/recursosgeneticos-forestales/identificado_pinus_pinaster.aspx\#]

De las Heras J, Moya D, Vega JA, Daskalakou E, Vallejo R, Grigoriadis N, Tsitsoni T, Baeza J, Valdecantos A, Fernández C, Espelta J, 
Fernandes P (2012) Post-fire management of serotinous pine forests. In: Moreira F, Arianoutsou M, Corona P, De las Heras J (eds) Postfire management and restoration of Southern European forests, managing forest ecosystems 24. Springer, Dordrecht, pp 121-150

Delgado J, Serrano J, López F, Acosta F (2001) Heat shock, mass dependent germination, and seed yield as related components of fitness of Cistus ladanifer. Environ Exp Bot 46:11-20. doi:10.1016/S00988472(01)00076-4

Escudero A, Sanz MV, Pita JM, Pérez-García F (1999) Probability of germination after heat treatment of native Spanish pines. Ann For Sci 56:511-520. doi:10.1051/forest:2001137

Escudero A, Núñez Y, Pérez-García F (2000) Is fire a selective force of seed size in pine species? Acta Oecol 21:245-256. doi:10.1016/ S1146-609X(00)01083-3

Escudero A, Pérez-García F, Luzuriaga AL (2002) Effects of light, temperature and population variability on the germination of seven Spanish pines. Seed Sci Res 12:261-271. doi:10.1079/SSR2002116

Espelta JM, Arnan X, Rodrigo A (2011) Non-fire induced seed release in a weakly serotinous pine: climatic factors, maintenance costs or both? Oikos 120:1752-1760. doi:10.1111/j.1600-0706.2011. 19570.x

Fernandes PM, Rigolot E (2007) The fire ecology and management of maritime pine (Pinus pinaster Ait.). For Ecol Manag 241:1-13. doi: 10.1016/j.foreco.2007.01.010

Ganatsas P, Tsakaldimo M, Thanos C (2008) Seed and cone diversity and seed germination of Pinus pinea in Strofylia Site of the Natura 2000 Network. Biodivers Conserv 17:2427-2439. doi:10.1016/j.jnc. 2009.04.006

Ghildiyal SK, Sharma CM, Gairola S (2009) Environmental variation in seed and seedling characteristics of Pinus roxburghii Sarg. from Uttarakhand, India. Appl Ecol Env Res 7:121-129

Gil L, López R, García-Mateos A, González-Doncel I (2009) Seed provenance and fire-related reproductive traits of Pinus pinaster in central Spain. Int J Wildland Fire 18:1003-1009. doi:10.1071/ WF08101

Goubitz S, Werger MJA, Ne'eman G (2003) Germination response to fire-related factors of seeds from non-serotinous and serotinous cones. Plant Ecol 169:195-204. doi:10.1023/A:1026036332277

Goubitz S, Nathan R, Roitemberg R, Shmida A, Ne'eman G (2004) Canopy seed bank structure in relation to: fire, tree size and density. Plant Ecol 173:191-201. doi:10.1023/B:VEGE.0000029324. 40801.74

Habrouk A, Retana J, Espelta JM (1999) Role of heat tolerance and cone protection of seeds in the response of three pine species to wildfires. Plant Ecol 145:91-99. doi:10.1023/A:1009851614885

Hanley M, Unna J, Darvill B (2003) Seed size and germination response: a relationship for fire-following plant species exposed to thermal shock. Oecologia 134:18-22. doi:10.1007/s00442-002-1094-2

Hernández-Serrano A, Verdú M, González-Martínez SC, Pausas JG (2013) Fire structures pine serotiny at different scales. Am J Bot 100:2349-2356. doi:10.3732/ajb.1300182

Hernández-Serrano A, Verdú M, Santos-del-Blanco L, Climent J, González-Martínez SC, Pausas JG (2014) Heritability and quantitative genetic divergence of serotiny, a fire persistence plant trait. Ann Bot 114:571-577. doi:10.1093/aob/mcu142

Keeley J (1977) Seed production, seed population in soil, and seedling production after fire for two congeneric pairs of sprouting and nonsprouting chaparral shrubs. Ecology 58:820-829. doi:10.2307/ 1936217

Liu J, Bai Y, Lamb EG, Simpson D, Liu G, Wei Y, Wang D, McKenney DW, Papadopol P (2013) Patterns of cross-continental variation in tree seed mass in the Canadian boreal forest. PLoS ONE 8, e61060. doi:10.1371/journal.pone. 0061060

Madrigal J, Hernando C, Martínez E, Guijarro M, Díez C (2005) Regeneración post-incendio de Pinus pinaster Ait. en la Sierra de Guadarrama (Sistema Central, España): modelos descriptivos de los factores influyentes en la densidad inicial y la supervivencia. Invest Agrar: Sist Recur For 14:36-51

Madrigal J, Hernando C, Guijarro M (2011) El papel de la regeneración natural en la restauración tras grandes incendios forestales: el caso del pino negral. Boletín del CIDEU 10:5-22, ISSN 1885-5237

Martínez-Sánchez JJ, Marín A, Herranz JM, Ferrandis P, Heras J (1995) Effects of high temperatures on germination of Pinus halepensis Mill. and Pinus pinaster Aiton subsp. pinaster seeds in southeast Spain. Vegetatio 116:69-72. doi:10.1007/BF00045279

Metz J, Liancourt P, Kigel J, Harel D, Sternberg M, Tielboerger K (2010) Plant survival in relation to seed size along environmental gradients: a long-term study from semi-arid and Mediterranean annual plant communities. J Ecol 98:697-704. doi:10.1111/j.1365-2745.2010. 01652.x

Moles AT, Westoby M (2004) Seedling survival and seed size: a synthesis of the literature. J Ecol 92:372-383. doi:10.1111/j.0022-0477.2004. 00884.x

Moles AT, Westoby M (2006) Seed size and plant strategy across the whole life cycle. Oikos 113:91-105. doi:10.1111/j.0030-1299. 2006.14194.x

Moriondo M, Good P, Durao R, Bindi M, Giannakopoulos C, Corte-Real J (2006) Potential impact of climate change on fire risk in the Mediterranean area. Clim Res 31:85-95. doi:10.3354/cr031085

Moya D, Saracino A, Salvatore R, Lovreglio R, De las Heras J, Leone V (2008) Anatomic basis and insulation of serotinous cones in Pinus halepensis Mill. Trees 22:511-519. doi:10.1071/BT10193

Moya D, De las Heras J, Salvatore R, Valero E, Leone V (2013) Fire intensity and serotiny: response of germination and enzymatic activity in seeds of Pinus halepensis Mill. from southern Italy. Ann For Sci 70:49-59. doi:10.1007/s13595-012-0236-x

Odion DC, Davis FW (2000) Fire, soil heating, and the formation of vegetation patterns in chaparral. Ecol Monogr 70:149-169. doi:10. 1890/0012-9615(2000)070[0149:FSHATF]2.0.CO;2

Parker WC, Noland TL, Morneault AE (2006) The effects of seed mass on germination, seedling emergence, and early seedling growth of eastern white pine (Pinus strobus L.). New For 32:33-49. doi:10. 1007/s11056-005-3391-1

Pausas JG (2004) Changes in fire and climate in the eastern Iberian Peninsula (Mediterranean basin). Clim Chang 63:337-350. doi:10. 1023/B:CLIM.0000018508.94901.9c

Pausas JG (2015) Evolutionary fire ecology: lessons learned from pines. Trends Plant Sci. doi:10.1016/j.tplants.2015.03.001

Pausas JG, Bradstock RA, Keith DA, Keeley JE, The GCTE (Global Change of Terrestrial Ecosystems) Fire Network (2004) Plant functional traits in relation to fire in crown-fire ecosystems. Ecology 85: 1085-1100. doi:10.1890/02-4094

Pausas JG, Llovet J, Rodrigo A, Vallejo R (2008) Are wildfires a disaster in the Mediterranean basin? a review. Int J Wildland Fire 17:713723. doi:10.1071/WF07151

R Core Team (2014) R: A language and environment for statistical computing. R Foundation for Statistical Computing, Vienna, URL http://www.R-project.org/

Reich PB, Oleksyn J, Tjoelker MG (1994) Seed mass effects on germination and growth of diverse European Scots pine populations. Can J For Res 24:306-320. doi:10.1139/x94-044

Reyes O, Casal M (1995) Germination behaviour of three species of the genus Pinus in relation to high temperatures suffered during forest fires. Ann For Sci 52:385-392. doi:10.1051/forest:2001137

Reyes O, Casal M (2001) The influence of seed age on germinative response to the effects of fire in Pinus pinaster, Pinus radiata and Eucalyptus globulus. Ann For Sci 58:439-447. doi:10.1051/ forest: 19950408

Reyes O, Casal M (2002) Effect of high temperatures on cone opening and on the release and viability of Pinus pinaster and $P$. radiata seeds in NW Spain. Ann For Sci 59:327-334. doi:10.1051/ forest:2001137 
Reyes O, Casal M (2004) Effects of forest fire ash on germination and early growth of four Pinus species. Plant Ecol 175:81-89. doi:10. 1023/B:VEGE.0000048089.25497.0c

Reyes O, García-Duro J, Salgado J (2015) Fire affects soil organic matter and the emergence of Pinus radiata seedlings. Ann For Sci 72:267275. doi:10.1007/s13595-014-0427-8

Rodrigo A, Retana J, Picó FX (2004) Direct regeneration is not the only response of Mediterranean forests to large fires. Ecology 85:716729. doi:10.1890/02-0492

Ruano I, Del Peso C, Bravo F (2015) Post-dispersal predation of Pinus pinaster Aiton seeds: key factors and effects on belowground seed bank. Eur J For Res 134:309-318. doi:10.1007/s10342-014-0853-Z

Salvatore R, Moya D, Pulido L, Lovreglio R, López-Serrano FR, De las Heras J, Leone V (2010) Morphological and anatomical differences in Aleppo pine seeds from serotinous and non-serotinous cones. New For 39:329-341. doi:10.1007/s11056-009-9174-3

Saracino A, Pacella R, Leone V, Borghetti M (1997) Seed dispersal and changing seed characteristics in a Pinus halepensis Mill. forest after fire. Plant Ecol 130:13-19. doi:10.1023/A:1009765129920

Stock WD, Pate JS, Delfs J (1990) Influence of seed size and quality on seedling development under low nutrient conditions in five Australian and South African members of the Proteaceae. J Ecol 78:1005-1020. doi:10.2307/2260949

Tapias R, Gil L, Fuentes-Utrilla P, Pardos JA (2001) Canopy seed banks in Mediterranean pines of southeastern Spain: a comparison between Pinus halepensis Mill., Pinus pinaster Ait., Pinus nigra Arn. and Pinus pinea L. J Ecol 89:629-638. doi:10.1046/j.13652745.2001.00575.x

Tapias R, Climent J, Pardos JA, Gil L (2004) Life histories of Mediterranean pines. Plant Ecol 171:53-68. doi:10.1023/B:VEGE. 0000029383.72609.f0

Torres O, Calvo L, Valbuena L (2006) Influence of high temperatures on seed germination of a special Pinus pinaster stand adapted to frequent fires. Plant Ecol 186:129-136. doi:10.1007/s11253-006. 9117.4

Trabaud L (1979) Etude du comportament du feu dans la garrigue de chene kermes a partir des temperatures et des vitesses de propagation. Ann Sci For 36:13-38. doi:10.1051/forest/19790102

Trabaud L, Oustric J (1989) Influence du feu sur la germination des semences de quatre espèces ligneuses méditeranéennes à reproduction sexuée obligatoire. Seed Sci Technol 17:589-599

Vasques A, Maia P, Pedro M, Santos C, Vallejo VR, Keizer JJ (2012) Germination in five shrub species of Maritime Pine understory-does seed provenance matter? Ann For Sci 69:499-507. doi:10.1007/ s13595-012-0206-3

Vega JA, Fernández C, Pérez-Gorostiaga P, Fonturbel T (2008) The influence of fire severity, serotiny, and post-fire management on Pinus pinaster Ait. recruitment in three burnt areas in Galicia (NW Spain). For Ecol Manag 256:1596-1603. doi:10.1016/j. foreco.2008.07.005

Venables WN, Ripley BD (2002) Modern applied statistics with S, 4th edn. Springer, New York

Violle C, Castro H, Richarte J, Navas ML (2009) Intraspecific seed trait variations and competition: passive or adaptive response? Funct Ecol 23:612-620. doi:10.1111/j.1365-2435.2009.01539.x

Vivas M, Zas R, Sampedro L, Solla A (2013) Environmental maternal effects mediate the resistance of Maritime pine to biotic stress. PLoS ONE 8, e70148. doi:10.1371/journal.pone.0070148

Zas R, Sampedro L (2015) Heritability of seed weight in Maritime pine, a relevant trait in the transmission of environmental maternal effects. Heredity 114:116-124. doi:10.1038/hdy.2014.76

Zas R, Cendán C, Sampedro L (2013) Mediation of seed provisioning in the transmission of environmental maternal effects in Maritime pine (Pinus pinaster Aiton). Heredity 111:248-255. doi:10.1038/hdy. 2013.44 